\title{
Neutrophils Express Oncomodulin and Promote Optic Nerve Regeneration
}

\author{
Takuji Kurimoto, ${ }^{1,2,3}$ Yuqin Yin, ${ }^{1,3}$ Ghaith Habboub, ${ }^{1,3}$ Hui-Ya Gilbert, ${ }^{1}$ Yiqing Li, ${ }^{1,3}$ Shintaro Nakao, ${ }^{4}$ \\ Ali Hafezi-Moghadam, ${ }^{4}$ and Larry I. Benowitz ${ }^{1,3,4,5}$ \\ ${ }^{1}$ Laboratories for Neuroscience Research in Neurosurgery and F.M. Kirby Neurobiology Center, Children's Hospital, Boston, Massachussetts 02115, \\ ${ }^{2}$ Department of Ophthalmology, Osaka Medical College, Osaka 569-8686, Japan, and Departments of ${ }^{3}$ Surgery and ${ }^{4}$ Ophthalmology and ${ }^{5}$ Program in \\ Neuroscience, Harvard Medical School, Boston, Massachusetts 02115
}

\begin{abstract}
Although neurons are normally unable to regenerate their axons after injury to the CNS, this situation can be partially reversed by activating the innate immune system. In a widely studied instance of this phenomenon, proinflammatory agents have been shown to cause retinal ganglion cells, the projection neurons of the eye, to regenerate lengthy axons through the injured optic nerve. However, the role of different molecules and cell populations in mediating this phenomenon remains unclear. We show here that neutrophils, the first responders of the innate immune system, play a central role in inflammation-induced regeneration. Numerous neutrophils enter the mouse eye within a few hours of inducing an inflammatory reaction and express high levels of the atypical growth factor oncomodulin $(0 \mathrm{~cm})$. Immunodepletion of neutrophils diminished $0 \mathrm{~cm}$ levels in the eye without altering levels of CNTF, leukemia inhibitory factor, or IL-6, and suppressed the proregenerative effects of inflammation. A peptide antagonist of $0 \mathrm{~cm}$ suppressed regeneration as effectively as neutrophil depletion. Macrophages enter the eye later in the inflammatory process but appear to be insufficient to stimulate extensive regeneration in the absence of neutrophils. These data provide the first evidence that neutrophils are a major source of $0 \mathrm{~cm}$ and can promote axon regeneration in the CNS.
\end{abstract}

\section{Introduction}

Neural injury activates an inflammatory response that can profoundly influence neurological outcome (Popovich and Longbrake, 2008). In the peripheral nervous system, the innate immune response that accompanies peripheral nerve damage plays an essential role in enabling sensory and motor neurons to regenerate axons back to their peripheral targets (Barrette et al., 2008). In addition, inducing an inflammatory reaction within dorsal root ganglia enhances the ability of sensory neurons to regenerate their central axon branches through the dorsal roots (Lu and Richardson, 1991; Steinmetz et al., 2005). Within the CNS, inflammation enables injured corticospinal tract axons to sprout collaterals in response to neurotrophin-3 (Chen et al., 2008), and inducing an inflammatory response within the spinal cord enhances the regeneration of axons arising from sensory neurons, but has deleterious effects as well (Horn et al., 2008; Gensel et al., 2009).

\footnotetext{
Received Nov. 27, 2012; revised July 19, 2013; accepted July 31, 2013.

Author contributions: G.H., A.H.-M., and L.I.B. designed research;T.K.,Y.Y., G.H., H.-Y.G.,Y.L., and S.N. performed research; T.K. and Y.Y. analyzed data; T.K. and L.I.B. wrote the paper.

This work was supported by the National Eye Institute (EY05690 to L.I.B.), Kawasaki Medical School Alumni Association Fund for Foreign Study (to T.K.), a Grant-in-Aid for Young Scientists B (23792021 to T.K.), and the Dr. Miriam and Sheldon G. Adelson Medical Research Foundation (to L.I.B.). We thank the Intellectual and Developmental Disabilities Research Center of Children's Hospital (National Institutes of Health P30 HD018655) for use of the Histology, Image Analysis, and Animal Behavior Cores.

Correspondence should be addressed to Dr. Larry Benowitz, CLSB 13071, Children's Hospital, 300 Longwood Avenue, Boston, MA 02115. E-mail: larry.benowitz@childrens.harvard.edu.

DOI:10.1523/JNEUROSCI.5511-12.2013

Copyright $\odot 2013$ the authors $\quad 0270-6474 / 13 / 3314816-09 \$ 15.00 / 0$
}

The most widely studied example of inflammation-induced regeneration is in the primary visual pathway. Retinal ganglion cells (RGCs), the projection neurons of the eye, are normally unable to regenerate their axons following optic nerve injury, but become able to do so after inducing an inflammatory reaction in the eye (Leon et al., 2000; Yin et al., 2003). Inflammation leads to a dramatic increase in the expression of oncomodulin $(\mathrm{Ocm})$, a small $\mathrm{Ca}^{2+}$-binding protein that plays a key role in inflammation-induced regeneration (Yin et al., 2006, 2009; Kurimoto et al., 2010). However, there is still some uncertainty about the cellular source of $\mathrm{Ocm}$ and, more generally, about the contributions of different cell types in stimulating regeneration. Ocm was identified as an axon-promoting factor secreted by a macrophage cell line in culture (Yin et al., 2006). However, levels of $\mathrm{Ocm}$ mRNA peak within a day of inducing an inflammatory response, when the macrophage response is just beginning (Yin et al., 2009). In addition, one study partially reduced the macrophage response and found no decrement in regeneration following injury to the lens, a manipulation that normally induces inflammation and axon regeneration (Hauk et al., 2008). These findings suggest the possibility that cells other than macrophages may be the principal regulators of optic nerve regeneration. We show here that in mice, neutrophils, the first responders of the innate immune system, enter the eye in great numbers within $12 \mathrm{~h}$ of inducing inflammation, produce high levels of $\mathrm{Ocm}$, and play an essential role in stimulating axon regeneration. Neutrophils were recently shown to be neuroprotective after spinal cord injury (Stirling et al., 2009), but appear not to play a major role in peripheral nerve regeneration (Nadeau et al., 2011). 


\section{Materials and Methods}

Surgery. Studies were performed at Children's Hospital Boston, Osaka Medical School (Osaka, Japan), and Massachusetts Eye and Ear Infirmary with the approval of the respective institutional animal care and use committees. The experiments used adult male C57B6 mice 8 weeks of age (average body weight, 20-26 g).

Optic nerve surgery was performed as in our previous studies (Yin et al., 2009; Kurimoto et al., 2010). Mice were anesthetized with either ketamine/xylazine or a mixture of isofluorane and oxygen while immobilized in a stereotaxic head holder. The optic nerve was exposed and crushed with microforceps for $5 \mathrm{~s}$. Zymosan $(12.5 \mathrm{mg} / \mathrm{ml}$, sterilized $)$ was injected intraocularly immediately afterward. At the conclusion of the studies, mice were perfused with saline followed by $4 \%$ paraformaldehyde. Optic nerves and eyes, or in some cases retinas, were carefully dissected for further analysis. In other cases, the vitreous was removed from the eyes of unfixed mice to analyze infiltrative cells. Results are based on a minimum of five mice per group.

Immunodepletion of neutrophils. A purified anti-mouse Ly6G antibody (Clone 1A8, BD PharMingen) or isotype-matched IgG (Sigma-Aldrich) was injected both retro-orbitally (100 $\mu \mathrm{g}$; Li et al., 2011) and intraperitoneally $(20 \mu \mathrm{g})$ before optic nerve crush using a modification of a previously published protocol (Daley et al., 2008). Preliminary experiments confirmed a dramatic decline in peripheral neutrophils following this procedure, as reported previously (Daley et al., 2008). Immunohistochemical results are based on a minimum of four retinas.

Purification and stimulation of peripheral neutrophils. Neutrophils were isolated as described previously (de Resende et al., 2010). Ten milliliters of blood were collected from the heart, added to $25 \mathrm{ml}$ of normal saline containing $0.5 \mathrm{M}$ EDTA, and centrifuged at $1200 \mathrm{rpm}$ for $10 \mathrm{~min}$. Serum was carefully removed to avoid disrupting the white blood cells (WBCs) over the red blood cells (RBCs). RBCs were lysed with a buffer containing $0.15 \mathrm{M} \mathrm{NH}_{4} \mathrm{Cl}, 10 \mathrm{mM} \mathrm{KHCO}_{3}$, and $0.1 \mathrm{~mm} \mathrm{EDTA}$ at $37^{\circ} \mathrm{C}$ for 5 min with continuous shaking. After centrifugation and washing with PBS, WBCs were resuspended in Percoll solution prepared as follows: nine volumes of Percoll and one volume of $10 \times$ PBS were mixed (100\%) and WBCs were separated on a discontinuous gradient of Percoll diluted to 61.5 and $76 \%$ in $1 \times$ PBS. Gradients were centrifuged at $3000 \mathrm{rpm}$ for $20 \mathrm{~min}$. The interface between plasma and $61.5 \%$ Percoll contains lymphocytes and monocytes, whereas the interface between 61.5 and $76 \%$ Percoll contains neutrophils. Neutrophils were aspirated carefully from this interface to examine their morphological characteristics and incubate in the presence or absence of zymosan $(1.25 \mathrm{mg} / \mathrm{ml}$ in DMEM). After $4 \mathrm{~h}$ in culture, blood neutrophils were collected and total RNA was extracted for realtime RT-PCR (see below).

Characterization of infiltrative cells in the aqueous/vitreous fluid. To observe the effects of injecting zymosan intraocularly, paraffin sections through the eye were stained with hematoxylin-eosin. In other cases, cryostat sections through the eye or isolated infiltrative cells were immunostained with monoclonal antibodies to granulocyte receptor-1 (Gr-1; Clone RB6-8C, Serotec) to stain neutrophils, F4/80 (Clone A3-1, Serotec) to stain macrophages, and/or an affinity-purified rabbit antibody to $\mathrm{Ocm}$ (Yin et al., 2009). For other experiments, infiltrative cells in the eye were obtained from the aqueous/vitreous fluid of mice at time points ranging from $6 \mathrm{~h}$ to $3 \mathrm{~d}$ after intraocular zymosan injections ( $4-6$ eyes for each time point). A thin layer of cells was spread onto coverslips and fixed with 4\% PFA after allowing 2-5 min for cells to become nearly dry and adhere. Cells were treated with a blocking buffer containing $10 \%$ normal goat serum in TBS, permeated with buffered $0.1 \%$ Triton X-100, then incubated with primary antibodies to Ocm and either Gr-1 or F4/80 at $4^{\circ} \mathrm{C}$ overnight. Following multiple rinses, Alexa-488-conjugated and Alexa-594-conjugated secondary antibodies were applied at a concentration of 1:500 for $1 \mathrm{~h}$. Cells were stained with DAPI and mounted.

Immunostaining for Ocm and other growth factors in retina. After blocking with the appropriate sera, retinal sections were incubated overnight at $4^{\circ} \mathrm{C}$ with primary antibodies to either $\mathrm{Ocm}$ (1:2000, rabbit polyclonal, custom-made), CNTF (1:2000, made in rabbit; Serotec), leukemia inhibitory factor (LIF, 1:100, rabbit; Santa Cruz Biotechnology), or IL-6 (1: 100, rabbit; Santa Cruz Biotechnology), washed 3 times, incubated with the appropriate secondary antibodies for $2 \mathrm{~h}$ at room temperature, washed $3 \times$, mounted, and covered. The intensity of immunostaining in the inner plexiform layer of the retina was evaluated by ImageJ software and was corrected by the staining intensity of retinas stained with an appropriate control antibody. Retinal layers were identified by DAPI staining. The average intensity of the staining was calculated from four individual cases per condition.

Fluorescence-activated cell sorting. At various times after zymosan injections, eyes were harvested, diced, and digested with collagenase (65U/ $\mathrm{ml}$; Wako) and hyaluronidase (220U/ml; Sigma-Aldrich) for $30 \mathrm{~min}$ at $37^{\circ} \mathrm{C}$ in a shaking water bath. Dissociated cells were collected and incubated with blocking reagent, monoclonal CD16/32 antibody (BD PharMingen), for $30 \mathrm{~min}$ at room temperature, then with rat monoclonal antibodies to Gr-1 and F4/80 conjugated to FITC or Alexa-647. After washing with PBS, cells were applied to a FACSAria III instrument (BD PharMingen). Cells were sorted using the criteria of $\mathrm{Gr}-1^{\text {high }} \mathrm{F} 4 / 80^{\text {neg }}$ (neutrophils) or Gr-1 ${ }^{\text {low }} \mathrm{F} 4 / 80^{\text {high }}$ (macrophages). Gr-1 is a cell-surface antigen whose expression is related to myeloid differentiation and is a member of the Ly6 gene family (Tepper et al., 1992). The Gr-1 antibody used (RB6-8C) reacts with both Ly6G, which is expressed abundantly on the surface of mature neutrophils, and Ly6C, which is expressed in neutrophils, dendritic cells, and in subpopulations of lymphocytes and monocytes (Hestdal et al., 1991; Fleming et al., 1993). The Gr-1 antibody binds mainly to mature neutrophils (Hestdal et al., 1991). F4/80 is a specific plasma membrane marker for mouse macrophages (Austyn and Gordon, 1981; Lawson et al., 1990) and, as shown earlier, cells that express high levels of F4/80 and low levels of Gr-1 are macrophages (Sica et al., 2007). A total of 10,000 cells were analyzed in each experiment. Experiments were repeated four times for each time point for each experimental procedure.

Quantitative reverse-transcription $P C R$. Ocm mRNA levels were quantified in sorted cells that were either Gr- ${ }^{\text {high }} \mathrm{F} 4 / 80^{\text {neg }}$ (neutrophils) or Gr- $1^{\text {low }} \mathrm{F} 4 / 80^{\text {high }}$ (macrophages) derived either from the eye or from peripheral blood (neutrophils only). One day after intraocular zymosan injections, cells from the eye were prepared as above and then immediately immersed into RNAlater (Qiagen). RNA was extracted using RNeasy (Qiagen) and was reverse-transcribed using an iScript cDNA Synthesis Kit (Bio-Rad) to make cDNA. The Ocm primers for qPCR are as described previously (Yin et al., 2009): forward: CCAAGACCCGACACCTTTGA; reverse: GGCTGGCAGACATCTTGGAG. Quantitative reverse-transcription PCR (qRT-PCR) was performed with iQSYBR Green Supermix Kit (Bio-Rad). The fold change in each sample was normalized first by the level of 18S RNA and then by the value of the normal retina. Quantititative PCR results are based on 2-4 biological replicates, with duplicate samples from each.

Axon regeneration and $R G C$ survival in vivo. Axon regeneration and RGC survival were evaluated after a $14 \mathrm{~d}$ survival period as described previously (Leon et al., 2000; Yin et al., 2006; Kurimoto et al., 2010). Operated mice were killed with an overdose of isofluorane and perfused with heparin-saline followed by $4 \%$ paraformaldehyde. Longitudinal sections through the optic nerves $(14 \mu \mathrm{m})$ were cut on a cryostat and GAP-43 immunostaining was performed to visualize regenerating axons. GAP-43-positive axons were counted manually in at least eight sections per case at prespecified distances from the injury site, and these values were used to estimate the total number of regenerating axons per nerve (Leon et al., 2000). Whole retinas were immunostained for $\beta$ III-tubulin (1:500; Clone TUJ1, Abcam), which, in the ganglion cell layer, is expressed selectively in RGCs (Cui et al., 2003; Yin et al., 2003). TUJ1+ cells were counted using ImageJ software in eight fields per case distributed in four quadrants of the eye at prespecified distances from the optic disc using a BX-50 microscope (Nikon). Cell survival is reported as the number of TUJ1+ cells per $\mathrm{mm}^{2}$ averaged over the eight fields sampled in each retina and then averaged across all cases within each experimental group. Quantitation of regeneration and cell survival were based on 5-7 mice per condition.

Primary retinal cell culture. The procedure for the primary retinal cell cultures has been described previously (Yin et al., 2003, 2006). Briefly, RGCs were retrogradely labeled by injecting $2 \%$ Fluoro-Gold (FG; Fluorochrome) into the superior collicullus of rats 1 week before dissections. 
A

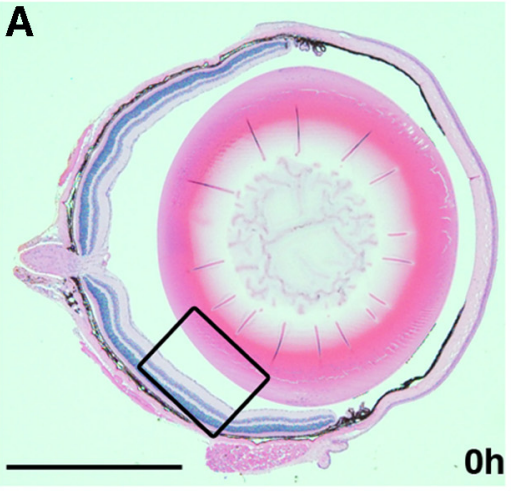

B
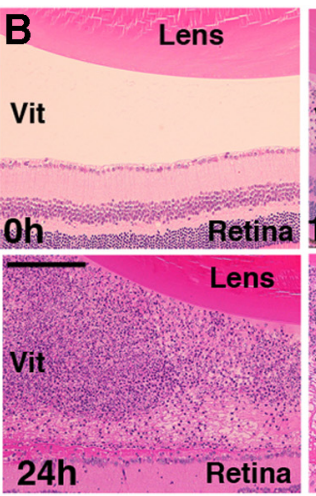
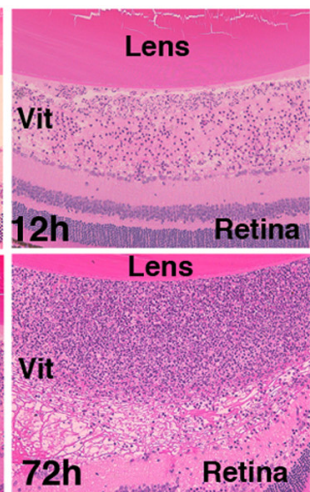

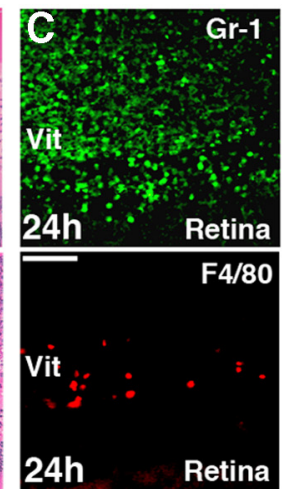

D
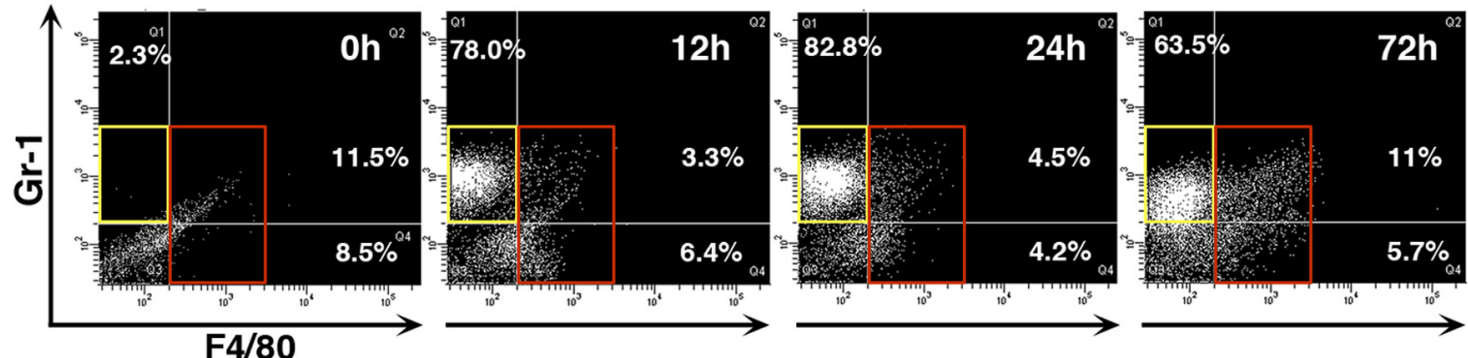

Figure 1. Characterization of inflammatory cells following zymosan injection. $\boldsymbol{A}$, Low-magnification image of the normal mouse eye. Rectangle indicates area shown in next panels. $\boldsymbol{B}$, Higher-magnification images show cells in the vitreous $12 \mathrm{~h}$ after intraocular injection of zymosan and greater numbers at $24 \mathrm{and} 72 \mathrm{~h}$. C, Immunostaining for F4/80, a macrophage-specific marker, and $\mathrm{Gr}-1$, a cell-surface marker expressed predominantly in neutrophils, $24 \mathrm{~h}$ after zymosan injection. $\boldsymbol{D}$, Representative analyses of inflammatory cells by flow cytometry. Few $\mathrm{Gr}-\mathrm{1}^{+}$or $\mathrm{F} 4 / 80^{+}{ }^{+}$cells are seen in the normal eye; 12 and $24 \mathrm{~h}$ after zymosan injection, there are large numbers of $\mathrm{Gr}-1^{+} / \mathrm{F} 4 / 80^{-}$neutrophils (yellow frames) and fewer $\mathrm{F} 4 / 80^{+}$macrophages (red frames). At $72 \mathrm{~h}$, the relative number of $\mathrm{F} 4 / 80^{+}$macrophages increases. Scale bars: $\boldsymbol{A}, 500 \mu \mathrm{m} ; \boldsymbol{B}, 200 \mu \mathrm{m} ; \boldsymbol{C}, 50 \mu \mathrm{m}$.

Retinas were dissected and digested with papain, and the dissociated cells were grown in a serum-free, L15-based culture medium. RGCs were identified by FG labeling and their axon growth and survival were evaluated after $3 \mathrm{~d}$ in culture. Samples were arranged in a pseudorandom fashion on the wells and were tested in quadruplicate, with the investigator blind to the treatment of the cells.

Statistical analyses. Data are presented as means \pm SEM. Significant differences were determined by unpaired Student's $t$ test or ANOVA with Dunnet's post hoc tests for multiple comparisons.

\section{Results}

\section{Characterization of the inflammatory response}

The posterior chamber of the eye normally contains very few cells. However, within $12 \mathrm{~h}$ of injecting zymosan, numerous cells appear (Fig. $1 A, B$ ), and by $24 \mathrm{~h}$, the posterior chamber is filled with infiltrative cells that persist for at least 2 more days (Fig. $1 B$ ). At low magnification, most of the cells seen at $24 \mathrm{~h}$ stain positively for Gr-1, while far fewer stain positively for F4/80 (Fig. 1C).

To characterize this response further, we dissociated the cells in the back of the eye and analyzed the cells by flow cytometry. On average, $74 \pm 4 \%$ of the cells present at $12 \mathrm{~h}$ were $\mathrm{Gr}-1^{\text {high }} \mathrm{F} 4 /$ $80^{\text {neg }}$ (i.e., neutrophils), whereas only $5.3 \pm 2.2 \%$ were Gr$1^{\text {low }} \mathrm{F} 4 / 80^{\text {pos }}$ (i.e., macrophages; average from four sorts). Most of the remainder were presumably other cells from the eye, including from the retina. Neutrophils continued to dominate at $24 \mathrm{~h}$, when $61 \pm 4 \%$ of the dissociated cells were $\mathrm{Gr}-1^{\text {high }} \mathrm{F} 4 / 80^{\text {neg }}$ (neutrophils) and $9.1 \pm 1.4 \%$ were Gr- $1^{\text {low }} \mathrm{F} 4 / 80^{\text {pos }}$ (macrophages). At $72 \mathrm{~h}$, the percentage of all cells sorted that were neutrophils declined slightly to $53 \pm 6.1 \%$, while the percentage that were macrophages was now $13.4 \pm 1.9 \%$. Thus, within the first $3 \mathrm{~d}$ of inducing an inflammatory response in the eye, neutrophils greatly outnumbered macrophages. Figure $1 D$ illustrates a representative output from flow cytometry. Note that these estimates are limited by the cutoffs used to distinguish high versus low levels of Gr-1 and F4/80 and by the presence or absence of other cell types (e.g., retinal neurons).

\section{Neutrophils express high levels of $\mathrm{Ocm}$}

As an alternative way to visualize infiltrative cells, we extracted the contents of the posterior chamber from unfixed eyes and displayed them directly on microscope slides. The vast majority of cells extracted this way at 12 and $24 \mathrm{~h}$ were Gr-1-positive (Fig. $2 A)$ and contained multisegmented nuclei, confirming their identity as neutrophils (Fig. 2C). Smaller numbers stained positively for F4/80 (Fig. 2B) and contained large, round nuclei, as expected for macrophages. Direct counting of all DAPI-positive cells $12 \mathrm{~h}$ after zymosan injection revealed that $78 \pm 4 \%$ showed high levels of Gr-1 and multisegmented nuclei, whereas $16 \pm 2 \%$ were positive for F4/80 and had round nuclei. The relative abundance of these cell types remained largely unchanged in material extracted at $24 \mathrm{~h}$, with neutrophils representing $80 \%$ of all DAPIpositive cells and macrophages $20 \%$. Of the cells that showed strong Gr-1-positive staining, neutrophils represented $96 \%$, thus validating the use of high $\mathrm{Gr}-1$ staining as a criterion to identify these cells (Fig. $2 G$ ). At $72 \mathrm{~h}$, the percentage of neutrophils decreased to $39 \pm 3 \%$ and the percentage of macrophages increased to $44 \pm 4 \%$ (change in values between 72 and $12 \mathrm{~h}$ are significant at $p<0.01$ for both types of cells; Fig. 2D). These values differ somewhat from those obtained by fluorescence-activated cell sorting (FACS), possibly because of (1) the cutoffs used to distinguish cells by FACS, as noted above; and (2) macrophages tended to adhere to the slides better than neutrophils, thus increasing their representation using the second method.

We previously found that $\mathrm{Ocm}$ plays a major role in mediating the effect of intraocular inflammation on optic nerve regeneration, 


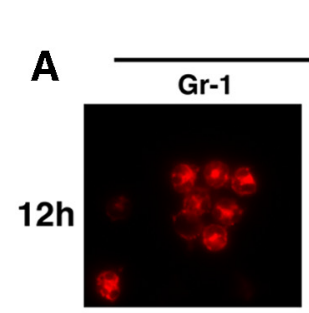

Neutrophils
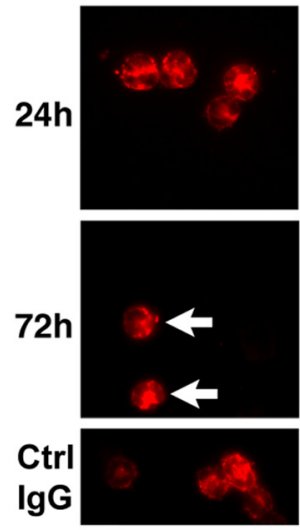

C

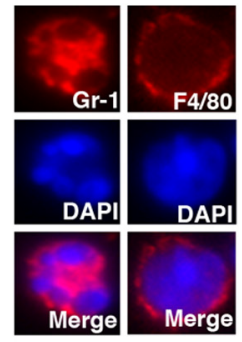

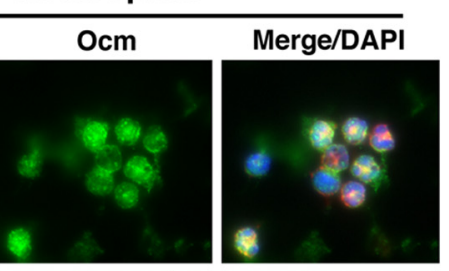
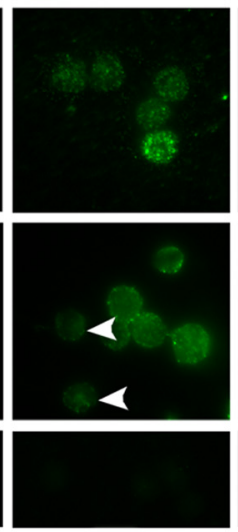

D

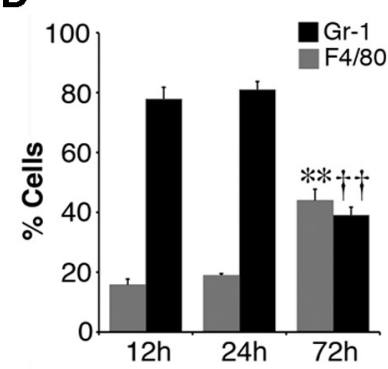

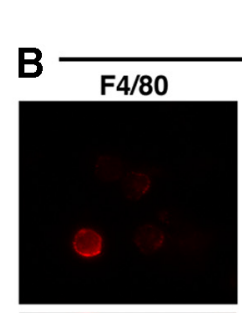


$E$

Macrophages
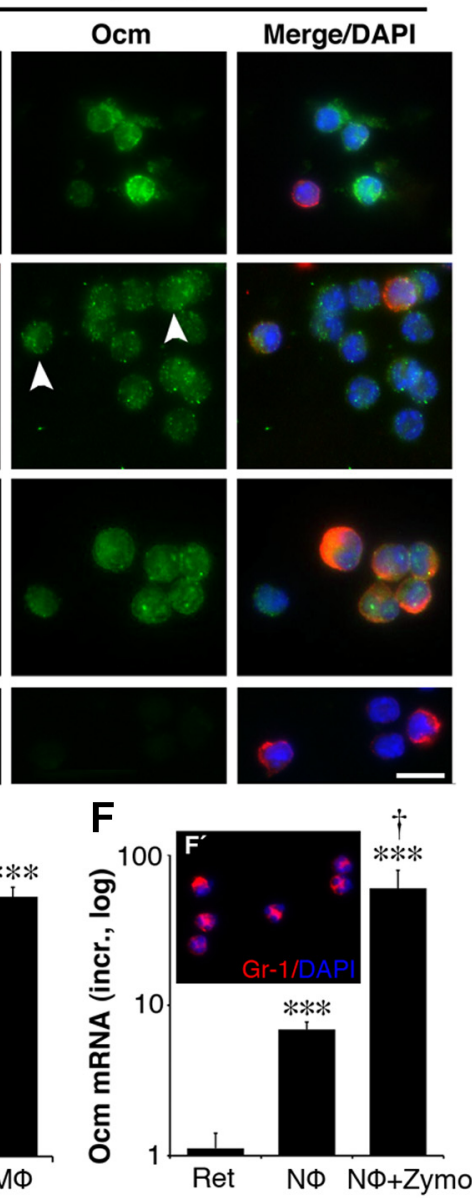

G
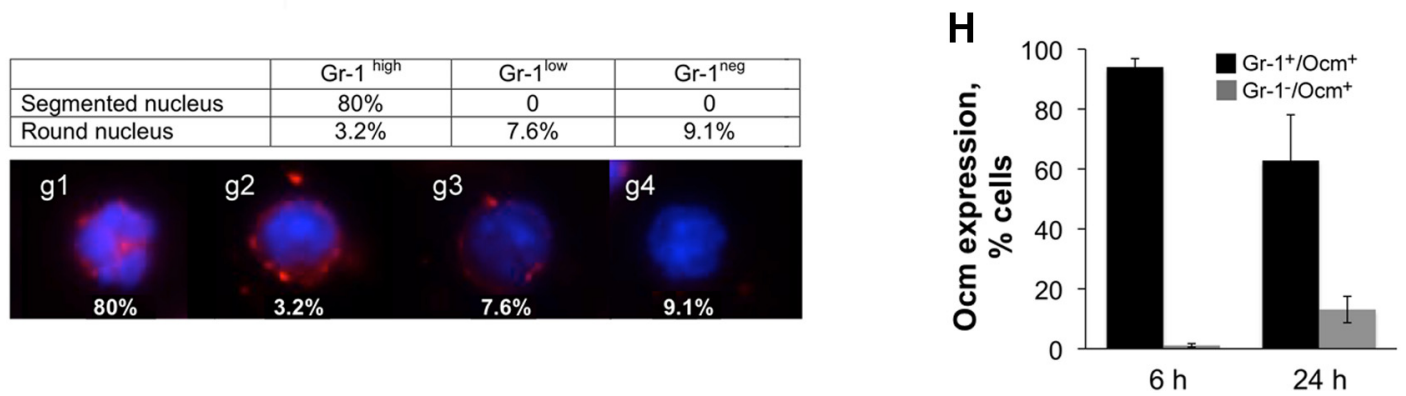

Figure 2. $0 \mathrm{~cm}$ is expressed in inflammatory cells. $A$, Double-immunostaining for $0 \mathrm{~cm}$ and $\mathrm{Gr}-1$ in cells extracted from the vitreous. Gr- $1^{+}$cells strongly express $0 \mathrm{~cm} 12 \mathrm{~h}$ after zymosan injection, but by $72 \mathrm{~h}, \mathrm{Gr}_{-1}{ }^{+}$cells (arrows) show little $0 \mathrm{~cm}$ expression (arrowheads). B, Double-immunostaining for $0 \mathrm{~cm}$ and F4/80. The number of F4/80 ${ }^{+}$cells (arrows) increases slowly, and they, to0, express $0 \mathrm{~cm}$ (arrowheads). Scale bar, $10 \mu \mathrm{m}$. C, Morphology of cells extracted from the vitreous at $24 \mathrm{~h}$. Cells that are strongly $\mathrm{Gr}-1^{+}$have lobulated nuclei, which is characteristic of neutrophils, whereas $\mathrm{F}_{4} / 80^{+}$macrophages have large, round nuclei. $\boldsymbol{D}$, Abundance of cells exhibiting strong staining for $\mathrm{Gr}-1$ or $\mathrm{F} 4 / 80$ after intraocular zymosan injections. Counts are based on direct visualization of cells extracted from the eye ( $N \geq 4$ biologically independent samples). $E$, $0 \mathrm{~cm}$ mRNA expression in FACS-sorted Gr- $1^{+} / F 4 / 80^{-}$cells (neutrophils) and Gr- ${ }^{+} / F 4 / 80^{+}$cells (macrophages) $24 \mathrm{~h}$ after zymosan injection. Data are normalized to $18 \mathrm{~S}$ RNA and then to $0 \mathrm{~cm}$ mRNA levels in the normal retina, and are represented on a logarithmic scale (means \pm SEM, $N=4$ independent sortings). Significance relative to the retina: ${ }^{*} p<0.05 ;{ }^{* * *} p<0.001 . F, F^{\prime}, 0 \mathrm{~cm}$ in peripheral neutrophils isolated from normal mouse blood. Untreated neutrophils express $0 \mathrm{~cm}$ $\left({ }^{* * *} p<0.001\right.$ compared with retina) and levels increase further following a $4 \mathrm{~h}$ exposure to zymosan ( $t p<0.05$ ). Results are normalized as above. G, Gr-1 expression and morphology of cells isolated from the eye $24 \mathrm{~h}$ after zymosan injection. Table shows percentage of cells exhibiting different levels of Gr-1 staining with either polymorphic nuclei, a hallmark of neutrophils, or round nuclei, a characteristic of macrophages (based on 185 cells counted). Ninety-six percent of cells with high Gr-1 staining are neutrophils. Panels below show cells with different characteristics. $g 1$, High $\mathrm{Gr}-1$, polymorphic nuclei (neutrophils); $\mathrm{g} 2-\mathrm{g} 4$, variable levels of $\mathrm{Gr}-1$ and round nuclei (macrophages). $\boldsymbol{H}, 0 \mathrm{~cm}$ expression. 0 ver $90 \%$ of cells with $\mathrm{Gr}-1$ staining express $0 \mathrm{~cm}$ at $6 \mathrm{~h}$. The number of Gr-1-positive cells that show appreciable $0 \mathrm{~cm}$ immunostaining declines by $24 \mathrm{~h}$, as $\mathrm{Gr}-1$-negative cells that express $0 \mathrm{~cm}$ start to appear (based on $200-400$ cells in 3-4 independent samples for each time point).

and that macrophages express Ocm (Yin et al., 2006, 2009). However, we did not investigate whether other cell types might express $\mathrm{Ocm}$ as well. Double-immunostaining revealed high levels of $\mathrm{Ocm}$ in Gr-1-positive neutrophils at $12 \mathrm{~h}$ and increasingly lower levels at 24 and $72 \mathrm{~h}$ (Fig. 2A). Use of a control rabbit IgG (Fig. 2A, bottom) resulted in no cell staining. $\mathrm{Ocm}$ was also seen in cells that are F4/80- positive (i.e., macrophages; Fig. $2 B$ ), which, as noted above, were far less numerous within the first day when levels of Ocm mRNA and protein reach peak levels (Yin et al., 2009). At the earliest time point examined, $6 \mathrm{~h}, \sim 95 \%$ of cells with strong Gr-1 staining expressed $\mathrm{Ocm}$. This number decreased at $24 \mathrm{~h}$, at which time Ocm-positive macrophages began to appear (Fig. 2H). 
qRT-PCR confirmed that both neutrophils and macrophages express high levels of Ocm mRNA. qRT-PCR was performed on RNA extracted from both Gr- $1^{\text {high }} \mathrm{F} 4 /$ $80^{\text {neg }}$ cells (neutrophils) and Gr- $1^{\text {low }}$ 4 / $80^{\text {pos }}$ cells (macrophages) extracted from the eye at $24 \mathrm{~h}$ and separated by FACS (Fig. 2E). Values were normalized by levels of 18s RNA and then by levels of $\mathrm{Ocm}$ mRNA:18s RNA in the normal retina. Neutrophils were found to express $\sim 15 \times$ as much Ocm mRNA as normal retina, whereas macrophages expressed $\sim 45 \times$ more Ocm mRNA than retina (Fig. $2 E$ ). We do not know how these mRNA levels translate into relative amounts of protein expressed and secreted.

We also investigated whether circulating neutrophils express $\mathrm{Ocm}$. Neutrophils were isolated from the blood of normal mice by density centrifugation (Fig. $2 F^{\prime}$ ) and were then either exposed to zymosan or left untreated for $4 \mathrm{~h}$. qRT-PCR revealed that untreated neutrophils expressed $\sim 7 \times$ as much Ocm mRNA as normal retina, while exposure to zymosan increased expression to $\sim 70$-fold more (Fig. $2 F$ ). Thus, peripheral blood neutrophils normally express $\mathrm{Ocm}$ and upregulate expression when activated.

\section{Immune depletion of neutrophils} diminishes $\mathrm{Ocm}$ levels in the retina We previously found that Ocm mRNA levels reach a peak within a day after inducing intraocular inflammation (Yin et al., 2009). As shown here, neutrophils greatly outnumber macrophages at this stage, suggesting that neutrophils may be the major source of $\mathrm{Ocm}$ and may therefore be critical for optic nerve regeneration. To investigate this possibility, we immunedepleted neutrophils using a modification of a previously described method (Daley et al., 2008). Hemotoxylineosin staining of whole eyes showed that this procedure diminished the overall number of infiltrative cells in the vitreous (Fig. 3A), and immunostaining for Gr-1 demonstrated a strong decline in Gr-1positive cells at 24 (Fig. $3 \mathrm{~B}$ ) and $72 \mathrm{~h}$ (data not shown). This decrease was further confirmed by flow cytometry, which showed a marked decline in the total number of cells in the eye after immunodepleting neutrophils before zymosan treatment, particularly for Gr- ${ }^{\text {high }} \mathrm{F} 4$ / $80^{\text {neg }}$ cells (changes significant at $p<0.001 ;$ Fig. $3 C, D$ ). Flow cytometry output in Figure $3 C$ is based on a fixed number of cells and, therefore, as the proportion of neutrophils decreases, the percentage of macrophages increases. However, the total number of macrophages does not appear to change. This has been shown more rigorously in other studies that depleted neutrophils using methods similar to those used here (Daley et al., 2008; (Nadeau et al., 2011).

As reported previously (Kurimoto et al., 2010), intraocular inflammation increases $\mathrm{Ocm}$ immunostaining in the retina. As shown in Figure $4 A$, levels of $\mathrm{Ocm}$ and members of the IL-6 cytokine family were not altered by systemic treatment with the control IgG. However, immune depletion of neutrophils using the LygG antibody diminished Ocm immunostaining by twothirds $(p<0.001)$ while not affecting levels of CNTF, LIF, or IL-6 (Fig. 4A-I).

\section{Neutrophil depletion diminishes axon regeneration}

In view of the evidence that neutrophils are a major source of $\mathrm{Ocm}$, we next investigated whether neutrophil depletion would suppress optic nerve regeneration. As expected, intraocular inflammation induced by zymosan enabled RGCs to regenerate their axons following optic nerve injury, and this effect remained high after treatment with control IgG (Fig. $4 \mathrm{~J}, K, M$; $p<0.001$ for zymosan alone or zymosan plus control IgG vs control). Immune depletion of neutrophils decreased the amount of regeneration by $70 \%$ (measured $500 \mu \mathrm{m}$ from the crush site; Fig. $4 L, M$; $p<0.05$ ).

We previously reported that blocking the effects of $\mathrm{Ocm}$ also suppresses regeneration (Yin et al., 2009). In view of the importance of this point for linking neutrophils to regeneration, we performed new studies to re-examine the role of Ocm in optic nerve regeneration. As shown in Figure 5, the control peptide $\mathrm{P} \alpha$ 

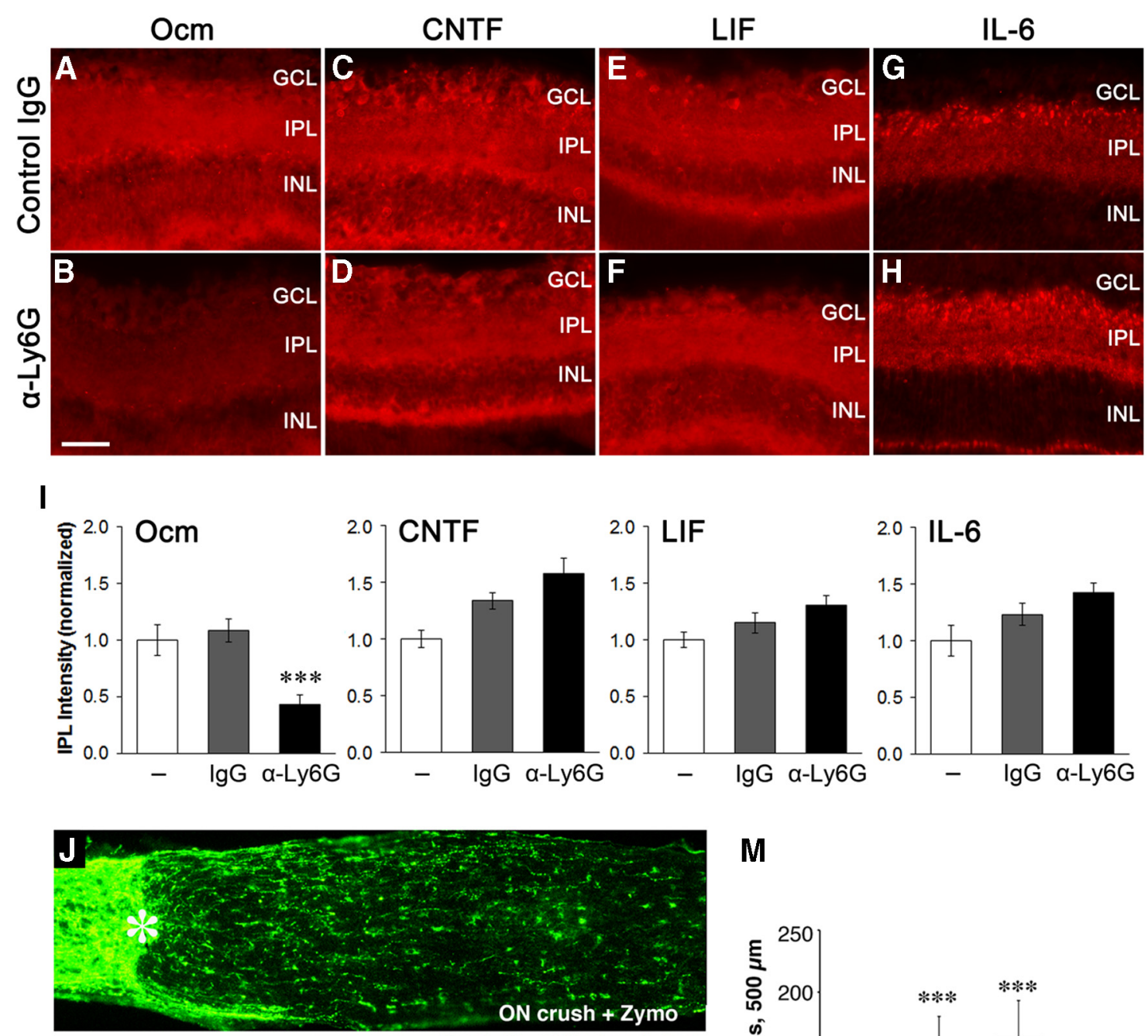

\section{M}
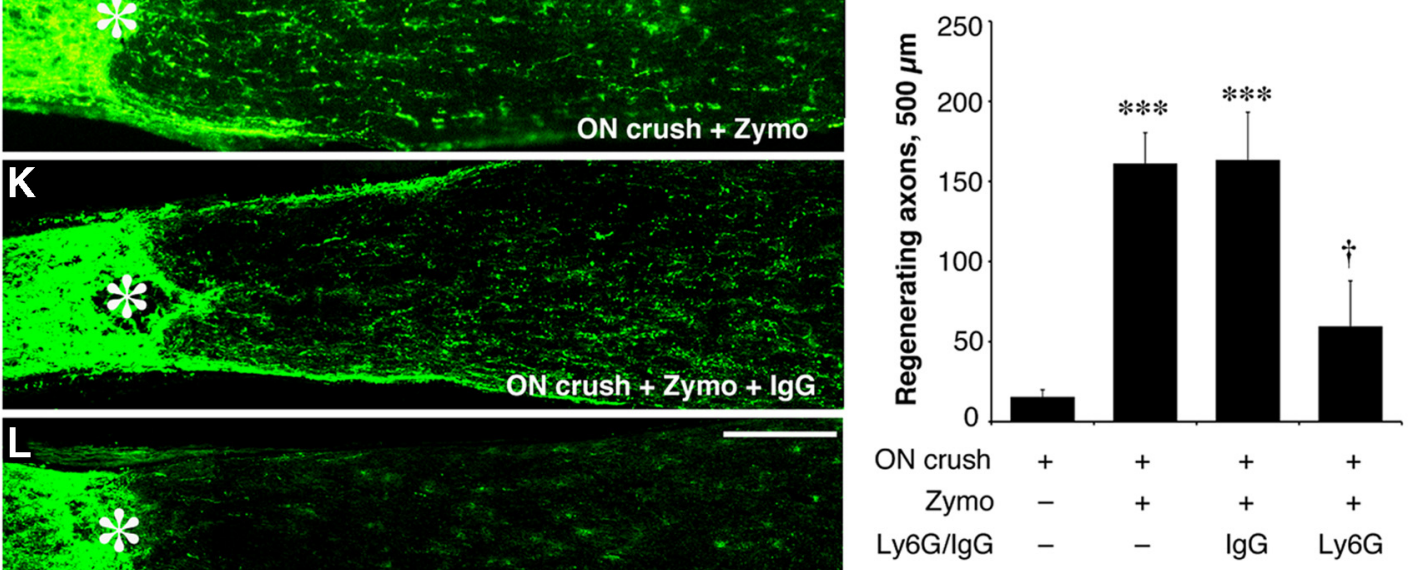

ON crush + Zymo $+\alpha-L y 6 G$

Figure 4. Neutrophil depletion decreases $0 \mathrm{~cm}$ levels in the retina and suppresses optic nerve regeneration. $\boldsymbol{A}-\boldsymbol{H}$, Immunostaining for the indicated growth factors $1 \mathrm{~d}$ after intraocular injection of zymosan and systemic treatment with control $\lg G(A, C, E, G)$ or anti- $\operatorname{Lg} 6 G(B, D, F, H) . I$, Quantitation of immunoreactivity. Control lgG did not alter immunostaining for any of the factors, whereas anti-Ly6G selectively diminished immunostaining for $0 \mathrm{~cm}$ ( $\dagger p<0.05 ; n \geq 4$ for each condition). J-M, Effect of neutrophil depletion on optic nerve regeneration. GAP-43 ${ }^{+}$axons are visualized by immunostaining in longitudinal sections through the mouse optic nerve 2 weeks after nerve injury and intraocular zymosan injections. Asterisks denote the injury site. Whereas treatment with control lgG had no effect (compare $\boldsymbol{K}, \boldsymbol{J}$ ), immune depletion of neutrophils with the anti-Ly $6 \mathrm{G}$ antibody suppressed regeneration $(\boldsymbol{L})$. $\boldsymbol{M}$, Quantitation. ${ }^{* * *}$ Increase relative to negative controls (optic nerve crush alone) significant at $p<0.001$. Decrease relative to controls treated with normal lgG significant at $p<0.05$. Results are based on $N \geq 4$ cases per condition. Scale bar: $\boldsymbol{A}-\boldsymbol{H}, 50 \mu \mathrm{m}$.

did not interfere with axon regeneration examined 2 weeks after optic nerve injury and intraocular zymosan. $\mathrm{P} \alpha$ is derived from the N-terminal region of $\alpha$-parvalbumin, a protein that is ancestrally related to $\mathrm{Ocm}$. However, P1, a peptide antagonist of $\mathrm{Ocm}$, suppressed regeneration by $70 \%$ (Fig. $5 A, B{ }^{* * *} p<0.001$ ). $\mathrm{P} 1$ is derived from the $\mathrm{N}$-terminal region of Ocm and competes with the native protein for receptor occupancy (Fig. $5 A, B ;{ }^{* * *} p<$
0.001). We next performed cell culture studies to test whether the effects of $\mathrm{P} 1$ are specific. In this culture system, mannose, which is abundant in the eye, stimulates some outgrowth when levels of cAMP are elevated (e.g., with forskolin; Li et al., 2003). Ocm increased the level of outgrowth induced by mannose and forskolin by $\sim 1.8$-fold (Fig. $5 C$; ${ }^{\star} p<0.05$, one-way ANOVA). At a 500:1 molar excess, P1 fully blocked this effect, bringing out- 
growth down to baseline (Fig. 5C). CNTF and LIF, tested at the same or higher concentrations as $\mathrm{Ocm}$, had a small effect that did not achieve statistical significance (ANOVA), perhaps due to the number of conditions tested, and $\mathrm{P} 1$ did not alter their effects (Fig. 5C). IL-6 had no effect. The inset in Figure $5 C^{\prime}$ shows a dose-response study for CNTF in the same culture system as in Figure 5C. CNTF achieved a maximal effect at $10 \mathrm{ng} / \mathrm{ml}$, far below the concentration used in the present study.

\section{Discussion}

This study demonstrates that neutrophils can promote axon regeneration in the optic nerve, a CNS pathway that normally shows almost no capacity for regeneration. Our prior studies had shown that intraocular inflammation, induced by injuring the lens or injecting zymosan into the eye, enables RGCs to regenerate lengthy axons through the adult optic nerve, and that this effect is mediated in large part by $\mathrm{Ocm}$ (Leon et al., 2000; Yin et al., 2006, 2009; Kurimoto et al., 2010). However, the role of specific cell types in this phenomenon has remained uncertain, as has the role of other trophic factors.

Ocm is a $12 \mathrm{kDa} \mathrm{Ca}^{2+}$-binding protein that was initially described in rat tumor cell lines (MacManus et al., 1982; Gillen et al., 1987; MacManus and Brewer, 1987) and later identified as a macrophagederived factor that promotes axon outgrowth from RGCs and peripheral sensory neurons (Yin et al., 2006). Although lacking a consensus signal sequence, $\mathrm{Ocm}$ is secreted from its cells of origin and binds to a cell-surface receptor on RGCs in a cAMP-dependent manner (Yin et al., 2006, 2009). Structurally, Ocm resembles $\alpha$-parvalbumin but with a distinctive, highly conserved $\mathrm{N}$-terminal region that is required for receptor binding (Yin et al., 2006). Levels of Ocm mRNA and protein rise dramatically in the eye within a day of injuring the lens or injecting zymosan into the eye (Yin et al., 2006, 2009). Gain-of-function studies show that slow release of Ocm and a cAMP analog from microspheres mimics the effects of intraocular inflammation, while loss-of-function studies show that a neutralizing antibody to $\mathrm{Ocm}$ or a blocking peptide suppresses inflammation-induced regeneration (Yin et al., 2006, 2009; Kurimoto et al., 2010). Although Ocm is expressed by activated macrophages, its expression peaks within a day of inducing inflammation, a time at which macrophages are first starting to appear (Yin et al., 2006). This discrepancy prompted us to investigate whether $\mathrm{Ocm}$ and the induction of regeneration might be associated with cells that enter the eye before macrophages (i.e., neutrophils).

Neutrophils are the first responders of the innate immune system and are activated by infection, injury, or ischemia (Schnell et al., 1999; Donnelly and Popovich, 2008). Neutrophils engulf invading bacteria and dying cells and release chemokines and other molecules that can either be beneficial or detrimental to neighboring cells (Nathan, 2006; Popovich and Longbrake, 2008; Brinkmann and Zychlinsky, 2012). Within 12-24 h after spinal cord injury, neutrophils are robustly recruited to the site of injury (Dusart and Schwab, 1994; Carlson et al., 1998; Stirling et al., 2009) and in this context appear to play a positive role, as immunodepleting these cells diminishes scar formation, tissue preservation, and behavioral outcome (Stirling et al., 2009). In our studies, numerous neutrophils were recruited into the eye by $12 \mathrm{~h}$ after zymosan injection and expressed high levels of Ocm mRNA and protein. $\mathrm{Ocm}$ immunostaining within neutrophils declined over time, perhaps due to secretion or to declining levels of expression. Immunodepletion of neutrophils decreased Ocm levels in the retina and, most significantly, suppressed axon regeneration.

Although many studies have confirmed the effects of proinflammatory agents in promoting optic nerve regeneration, the principle mediators of this phenomenon have been controversial. Different studies have proposed, for example, that regeneration is stimulated by trophic factors derived from the lens (Fischer et al., 
2000), a direct effect $\beta$ and $\gamma$ crystallin on RGCs (Fischer et al., 2008), or astrocyte-derived trophic factors (Logan et al., 2006; Lorber et al., 2009). One group has maintained that astrocytederived CNTF is the principle mediator of regeneration induced by lens injury and other proinflammatory agents, and that inflammatory cells and Ocm are uninvolved (Hauk et al., 2008, 2010; Leibinger et al., 2009). However, the near-complete loss of regeneration that is seen when $\mathrm{Ocm}$ is blocked suggests that neither CNTF nor any other factor can stimulate extensive regeneration on its own (Yin et al., 2009; Kurimoto et al., 2010). In agreement with this observation, many groups have failed to find a strong effect of CNTF on axon regeneration in cell culture (Cohen et al., 1994) or in vivo following direct intraocular injections (Leon et al., 2000; Pernet and Di Polo, 2006; Lingor et al., 2008; Smith et al., 2009) or when overexpressed in RGCs (Weise et al., 2000; Leaver et al., 2006). High concentrations of CNTF can stimulate axons to grow through a peripheral nerve graft attached to the cut end of the optic nerve, but this effect was shown to be due to the recruitment of macrophages (Cen et al., 2007). A complete knock-out of the cntf and lif genes blocks regeneration induced by lens injury in mice, but this could be a consequence of the loss of RGC viability that results from the double-gene deletion (Leibinger et al., 2009) or other undefined developmental changes. SOCS3 is an inhibitor of signaling in the jak-STAT pathway and suppresses CNTF signaling. Levels of SOC3 increase during development and increase even further following optic nerve injury and intraocular inflammation (Fischer et al., 2004; Park et al., 2009). Accordingly, the ability of CNTF to induce optic nerve regeneration in mature mice requires deletion of the socs3 gene in RGCs (Smith et al., 2009). The results of the present study confirm that $\mathrm{Ocm}$ mediates most of the effect of inflammation on optic nerve regeneration, and that in culture at least, the effects of CNTF and LIF are weak. CNTF nevertheless can promote RGC viability (Weise et al., 2000), and LIF may as well (Leibinger et al., 2009).

The strong reduction in regeneration seen after depleting neutrophils suggests that other cell types cannot induce extensive regeneration by themselves. It is possible, however, that neutrophils normally stimulate other cells to release relevant growth factors or that loss of neutrophils affects the subsequent inflammatory chain of events. However, our results indicate that macrophage activation persists after neutrophil depletion, as was previously reported by other studies using similar methods for immunodepletion (Daley et al., 2008; Stirling et al., 2009; Nadeau et al., 2011).

The present results contribute to our growing awareness of how the immune response can enhance outcome after CNS injury (Schwartz and Yoles, 2006; Benowitz and Popovich, 2011). We have recently shown that intraocular inflammation, when combined with deletion of the pten gene and elevation of cAMP levels, enables RGCs to regenerate axons through the entire length of the optic nerve and on into the lateral geniculate nucleus and other central target areas, where they form synapses and restore some visual responses (de Lima et al., 2012). These latter findings illustrate the potential for substantial functional recovery after optic nerve injury, and point to the need for greater understanding of the interactions between the immune system and the nervous system to help achieve this goal.

\section{References}

Austyn JM, Gordon S (1981) F4/80, a monoclonal antibody directed specifically against the mouse macrophage. Eur J Immunol 11:805-815. CrossRef Medline
Barrette B, Hébert MA, Filali M, Lafortune K, Vallières N, Gowing G, Julien JP, Lacroix S (2008) Requirement of myeloid cells for axon regeneration. J Neurosci 28:9363-9376. CrossRef Medline

Benowitz LI, Popovich PG (2011) Inflammation and axon regeneration. Curr Opin Neurol 24:577-583. CrossRef Medline

Brinkmann V, Zychlinsky A (2012) Neutrophil extracellular traps: is immunity the second function of chromatin? J Cell Biol 198:773-783. CrossRef Medline

Carlson SL, Parrish ME, Springer JE, Doty K, Dossett L (1998) Acute inflammatory response in spinal cord following impact injury. Exp Neurol 151:77-88. CrossRef Medline

Cen LP, Luo JM, Zhang CW, Fan YM, Song Y, So KF, van Rooijen N, Pang CP, Lam DS, Cui Q (2007) Chemotactic effect of ciliary neurotrophic factor on macrophages in retinal ganglion cell survival and axonal regeneration. Invest Ophthalmol Vis Sci 48:4257-4266. CrossRef Medline

Chen Q, Smith GM, Shine HD (2008) Immune activation is required for NT-3-induced axonal plasticity in chronic spinal cord injury. Exp Neurol 209:497-509. CrossRef Medline

Cohen A, Bray GM, Aguayo AJ (1994) Neurotrophin-4/5 (NT-4/5) increases adult rat retinal ganglion cell survival and neurite outgrowth in vitro. J Neurobiol 25:953-959. CrossRef Medline

Cui Q, Yip HK, Zhao RC, So KF, Harvey AR (2003) Intraocular elevation of cyclic AMP potentiates ciliary neurotrophic factor-induced regeneration of adult rat retinal ganglion cell axons. Mol Cell Neurosci 22:49-61. CrossRef Medline

Daley JM, Thomay AA, Connolly MD, Reichner JS, Albina JE (2008) Use of Ly6G-specific monoclonal antibody to deplete neutrophils in mice. J Leukoc Biol 83:64-70. Medline

de Lima S, Koriyama Y, Kurimoto T, Oliveira JT, Yin Y, Li Y, Gilbert HY, Fagiolini M, Martinez AM, Benowitz L (2012) Full-length axon regeneration in the adult mouse optic nerve and partial recovery of simple visual behaviors. Proc Natl Acad Sci U S A 109:9149-9154. CrossRef Medline

De Resende MM, Stodola TJ, Greene AS (2010) Role of the renin angiotensin system on bone marrow-derived stem cell function and its impact on skeletal muscle angiogenesis. Physiol Genomics 42:437-444. CrossRef Medline

Donnelly DJ, Popovich PG (2008) Inflammation and its role in neuroprotection, axonal regeneration and functional recovery after spinal cord injury. Exp Neurol 209:378-388. CrossRef Medline

Dusart I, Schwab ME (1994) Secondary cell death and the inflammatory reaction after dorsal hemisection of the rat spinal cord. Eur J Neurosci 6:712-724. CrossRef Medline

Fischer D, Pavlidis M, Thanos S (2000) Cataractogenic lens injury prevents traumatic ganglion cell death and promotes axonal regeneration both in vivo and in culture. Invest Ophthalmol Vis Sci 41:3943-3954. Medline

Fischer D, Petkova V, Thanos S, Benowitz LI (2004) Switching mature retinal ganglion cells to a robust growth state in vivo: gene expression and synergy with RhoA inactivation. J Neurosci 24:8726-8740. CrossRef Medline

Fischer D, Hauk TG, Müller A, Thanos S (2008) Crystallins of the beta/ gamma-superfamily mimic the effects of lens injury and promote axon regeneration. Mol Cell Neurosci 37:471-479. CrossRef Medline

Fleming TJ, Fleming ML, Malek TR (1993) Selective expression of Ly-6G on myeloid lineage cells in mouse bone marrow. RB6-8C5 mAb to granulocyte-differentiation antigen (Gr-1) detects members of the Ly-6 family. J Immunol 151:2399-2408. Medline

Gensel JC, Nakamura S, Guan Z, van Rooijen N, Ankeny DP, Popovich PG (2009) Macrophages promote axon regeneration with concurrent neurotoxicity. J Neurosci 29:3956-3968. CrossRef Medline

Gillen MF, Banville D, Rutledge RG, Narang S, Seligy VL, Whitfield JF, MacManus JP (1987) A complete complementary DNA for the oncodevelopmental calcium-binding protein, oncomodulin. J Biol Chem 262: 5308-5312. Medline

Hauk TG, Müller A, Lee J, Schwendener R, Fischer D (2008) Neuroprotective and axon growth promoting effects of intraocular inflammation do not depend on oncomodulin or the presence of large numbers of activated macrophages. Exp Neurol 209:469-482. CrossRef Medline

Hauk TG, Leibinger M, Müller A, Andreadaki A, Knippschild U, Fischer D (2010) Intravitreal application of the Toll-like receptor 2 agonist Pam3Cys stimulates axon regeneration in the mature optic nerve. Invest Ophthalmol Vis Sci 51:459-464. CrossRef Medline 
Hestdal K, Ruscetti FW, Ihle JN, Jacobsen SE, Dubois CM, Kopp WC, Longo DL, Keller JR (1991) Characterization and regulation of RB6-8C5 antigen expression on murine bone marrow cells. J Immunol 147:22-28. Medline

Horn KP, Busch SA, Hawthorne AL, van Rooijen N, Silver J (2008) Another barrier to regeneration in the CNS: activated macrophages induce extensive retraction of dystrophic axons through direct physical interactions. J Neurosci 28:9330-9341. CrossRef Medline

Kurimoto T, Yin Y, Omura K, Gilbert HY, Kim D, Cen LP, Moko L, Kügler S, Benowitz LI (2010) Long-distance axon regeneration in the mature optic nerve: contributions of oncomodulin, cAMP, and pten gene deletion. J Neurosci 30:15654-15663. CrossRef Medline

Lawson LJ, Perry VH, Dri P, Gordon S (1990) Heterogeneity in the distribution and morphology of microglia in the normal adult mouse brain. Neuroscience 39:151-170. CrossRef Medline

Leaver SG, Cui Q, Plant GW, Arulpragasam A, Hisheh S, Verhaagen J, Harvey AR (2006) AAV-mediated expression of CNTF promotes long-term survival and regeneration of adult rat retinal ganglion cells. Gene Ther 13:1328-1341. CrossRef Medline

Leibinger M, Müller A, Andreadaki A, Hauk TG, Kirsch M, Fischer D (2009) Neuroprotective and axon growth-promoting effects following inflammatory stimulation on mature retinal ganglion cells in mice depend on ciliary neurotrophic factor and leukemia inhibitory factor. J Neurosci 29:14334-14341. CrossRef Medline

Leon S, Yin Y, Nguyen J, Irwin N, Benowitz LI (2000) Lens injury stimulates axon regeneration in the mature rat optic nerve. J Neurosci 20:4615-4626. Medline

Li S, Li T, Luo Y, Yu H, Sun Y, Zhou H, Liang X, Huang J, Tang S (2011) Retro-orbital injection of FITC-dextran is an effective and economical method for observing mouse retinal vessels. Mol Vis 17:3566-3573. Medline

Li Y, Irwin N, Yin Y, Lanser M, Benowitz LI (2003) Axon regeneration in goldfish and rat retinal ganglion cells: differential responsiveness to carbohydrates and cAMP. J Neurosci 23:7830-7838. Medline

Lingor P, Tönges L, Pieper N, Bermel C, Barski E, Planchamp V, Bähr M (2008) ROCK inhibition and CNTF interact on intrinsic signalling pathways and differentially regulate survival and regeneration in retinal ganglion cells. Brain 131:250-263. Medline

Logan A, Ahmed Z, Baird A, Gonzalez AM, Berry M (2006) Neurotrophic factor synergy is required for neuronal survival and disinhibited axon regeneration after CNS injury. Brain 129:490-502. Medline

Lorber B, Berry M, Douglas MR, Nakazawa T, Logan A (2009) Activated retinal glia promote neurite outgrowth of retinal ganglion cells via apolipoprotein E. J Neurosci Res 87:2645-2652. CrossRef Medline

Lu X, Richardson PM (1991) Inflammation near the nerve cell body enhances axonal regeneration. J Neurosci 11:972-978. Medline

MacManus JP, Brewer LM (1987) Isolation, localization, and properties of the oncodevelopmental calcium-binding protein oncomodulin. Methods Enzymol 139:156-168. CrossRef Medline

MacManus JP, Whitfield JF, Boynton AL, Durkin JP, Swierenga SH (1982) Oncomodulin — a widely distributed, tumour-specific, calcium-binding protein. Oncodev Biol Med 3:79-90. Medline

Nadeau S, Filali M, Zhang J, Kerr BJ, Rivest S, Soulet D, Iwakura Y, de Rivero Vaccari JP, Keane RW, Lacroix S (2011) Functional recovery after pe- ripheral nerve injury is dependent on the pro-inflammatory cytokines IL-1 $\beta$ and TNF: implications for neuropathic pain. J Neurosci 31:1253312542. CrossRef Medline

Nathan C (2006) Neutrophils and immunity: challenges and opportunities. Nat Rev Immunol 6:173-182. CrossRef Medline

Park KK, Hu Y, Muhling J, Pollett MA, Dallimore EJ, Turnley AM, Cui Q, Harvey AR (2009) Cytokine-induced SOCS expression is inhibited by cAMP analogue: impact on regeneration in injured retina. Mol Cell Neurosci 41:313-324. CrossRef Medline

Pernet V, Di Polo A (2006) Synergistic action of brain-derived neurotrophic factor and lens injury promotes retinal ganglion cell survival, but leads to optic nerve dystrophy in vivo. Brain 129:1014-1026. CrossRef Medline

Popovich PG, Longbrake EE (2008) Can the immune system be harnessed to repair the CNS? Nat Rev Neurosci 9:481-493. CrossRef Medline

Schnell L, Fearn S, Klassen H, Schwab ME, Perry VH (1999) Acute inflammatory responses to mechanical lesions in the CNS: differences between brain and spinal cord. Eur J Neurosci 11:3648-3658. CrossRef Medline

Schwartz M, Yoles E (2006) Immune-based therapy for spinal cord repair: autologous macrophages and beyond. J Neurotrauma 23:360-370. CrossRef Medline

Sica A, Rubino L, Mancino A, Larghi P, Porta C, Rimoldi M, Solinas G, Locati M, Allavena P, Mantovani A (2007) Targeting tumour-associated macrophages. Expert Opin Ther Targets 11:1219-1229. CrossRef Medline

Smith PD, Sun F, Park KK, Cai B, Wang C, Kuwako K, Martinez-Carrasco I, Connolly L, He Z (2009) SOCS3 deletion promotes optic nerve regeneration in vivo. Neuron 64:617-623. CrossRef Medline

Steinmetz MP, Horn KP, Tom VJ, Miller JH, Busch SA, Nair D, Silver DJ, Silver J (2005) Chronic enhancement of the intrinsic growth capacity of sensory neurons combined with the degradation of inhibitory proteoglycans allows functional regeneration of sensory axons through the dorsal root entry zone in the mammalian spinal cord. J Neurosci 25:8066-8076. CrossRef Medline

Stirling DP, Liu S, Kubes P, Yong VW (2009) Depletion of Ly6G/Gr-1 leukocytes after spinal cord injury in mice alters wound healing and worsens neurological outcome. J Neurosci 29:753-764. CrossRef Medline

Tepper RI, Coffman RL, Leder P (1992) An eosinophil-dependent mechanism for the antitumor effect of interleukin-4. Science 257:548-551. CrossRef Medline

Weise J, Isenmann S, Klöcker N, Kügler S, Hirsch S, Gravel C, Bähr M (2000) Adenovirus-mediated expression of ciliary neurotrophic factor (CNTF) rescues axotomized rat retinal ganglion cells but does not support axonal regeneration in vivo. Neurobiol Dis 7:212-223. CrossRef Medline

Yin Y, Cui Q, Li Y, Irwin N, Fischer D, Harvey AR, Benowitz LI (2003) Macrophage-derived factors stimulate optic nerve regeneration. J Neurosci 23:2284-2293. Medline

Yin Y, Henzl MT, Lorber B, Nakazawa T, Thomas TT, Jiang F, Langer R, Benowitz LI (2006) Oncomodulin is a macrophage-derived signal for axon regeneration in retinal ganglion cells. Nat Neurosci 9:843-852. CrossRef Medline

Yin Y, Cui Q, Gilbert HY, Yang Y, Yang Z, Berlinicke C, Li Z, Zaverucha-doValle C, He H, Petkova V, Zack DJ, Benowitz LI (2009) Oncomodulin links inflammation to optic nerve regeneration. Proc Natl Acad Sci U S A 106:19587-19592. CrossRef Medline 